\title{
Smart City idea: use of people's opinions on the environmental threats for intelligent management of the city
}

doi:10.2478/mape-2019-0014

Date of submission to the Editor: 04/2018

Date of acceptance by the Editor: 07/2018

MAPE 2019, volume 2, issue 1, pp. 140-150

\author{
Jolanta Ignac-Nowicka* \\ ORCID ID: 0000-0002-8164-6326 \\ Silesian University of Technology, Poland \\ Danuta Zarebinska \\ Atria logic INC, USA \\ Wojciech Kaniak \\ Rexroth Bosch Group Canada, Canada
}

\section{INTRODUCTION}

Contemporary cities are subject to constant transformations, change their structures, develop intensively or enter a declining phase. These phenomena have many causes and are often influenced by factors independent of each other. Cities and urban areas are characterized by complex social, economic, spatial and environmental problems. The implementation of new technologies in the urban environment and care for the preservation of resources cause the emergence of new challenges for sustainable urban development. Such dynamics of changes in urban areas forces urban communities to look for more efficient and effective methods of managing urban affairs (Stawasz \& Sikora-Fernandez, 2016). Efficient and effective management of the city with the participation of its residents is a basic and important element of the idea of building smart cities. The basis for the functioning of an intelligent urban center is therefore creative social capital, which is the initiator and often the creator of innovative urban solutions systems. Smart city is a city of the future that can react quickly to any changes and at the same time limit excessive consumption of resources (Korenik, 2019, Kowalski, 2015). An intelligent city is a specific variant of a postindustrial city or a completely new urban center (Korenik, 2019).

In many approaches to defining the concept of "smart city", one common denominator can be seen - smart city is a city of creative thinking society that can use technical and technological innovations in its activities, and also use information and communication technologies ITC (Dobrowolski, 2005). Thanks to these technologies, smart cities use the available resources much more effectively to improve the quality of life in the city and ensure its sustainable development (Nam T. \& Pardo T.A., 2011). In a smart city, the priority is to identify factors limiting the development of the urban environment and meeting the needs of its residents to ensure their high standard of living. In debates on the functioning of smart cities, there is often a trend to build

\footnotetext{
* jolanta.ignac-nowicka@polsl.pl
} 
human-centered development programs. On the one hand, these programs focus on people and citizens living in intelligent cities, on the other hand, on the interdependencies between a given smart city and the context in which it is embedded (Szafraniec, 2017, Boryczka, 2016). An important element of city management is the management of natural resources of urban areas in such a way as to ensure the comfort of living for city dwellers (Bacco et al., 2017, Cooper \& Alley, 2011).

This article analyzes the needs of residents against the background of pollution of the natural environment, in particular air pollution in the city area. The research was carried out on the example of the Zabrze city in the Silesian agglomeration. Territorially the city of Zabrze covers an area of $80.4 \mathrm{~km}^{2}$ and is located in the Upper Silesian Industrial Region (Silesia). The city is inhabited by over 177,000 inhabitants. In 2016, Zabrze was the eighteenth most polluted city in the European Union. Therefore, there is a great need to analyze possible measures to improve the quality of atmospheric air and the comfort of living for the inhabitants of the cities of the Silesian Voivodeship.

\section{THE NATURAL ENVIRONMENT IN THE URBAN AREA}

In the urban environment, many factors related to the industrial and communication activities of humans influence the quality of air, soil and water. In the studied area of the Zabrze city, a close proximity of industrial plants with residential areas is observed. Low emission of a dense network of road transport and emission of pollutants from industrial plants affects the quality of atmospheric air (Kaczmarczyk et al., 2015). Taking into account the fact that the area of the Silesian Voivodship occupies only $3.9 \%$ of the country's area, the amount of substances emitted therein exacerbating the air condition is much higher than in other regions of Poland. On a local scale, the problem is even greater because the emission sources are mainly located in areas of high population density. A factor significantly affecting the spread of pollutants, especially in the urban area, is the type of urban development affecting the creation of so-called channels for discharging pollutants from a residential area.

A distinction is made between three agglomeration models: radial - concentric, carpet and banded, which is an ideal model for discharging pollutants from a given area (Ignac-Nowicka, 2018a, Vallero, 2008). Analysis of the location of residential buildings, industrial areas and road network, as well as green areas, allows assigning to the Silesia area a carpet type of urban agglomeration. The carpet type of urban buildings is the most unfavorable in terms of the efficiency of discharging pollutants from inhabited areas. The proximity of environmentally troublesome plants and a dense communication network means that regardless of the direction of the wind, the population is constantly exposed to the impact of air pollution emitted by industrial plants and low emissions (Avveduto et al., 2017).

The air pollution in the region of Silesia consists of emissions from industrial plants, road transport and for a few years also increased low emissions coming from home furnaces (Pikoń \& Farooq, 2017). This problem is particularly evident in the winter season, when intensive heating of residential premises takes place (Ignac-Nowicka, 2018a, Ignac-Nowicka, 2018b). This creates new challenges for local municipalities (Rzeńca, 2016). 


\section{METHODOLOGY AND TEST RESULTS}

Survey research was conducted among residents from various areas of the city. 580 respondents from the city of Zabrze from five age groups took part in the survey. The most numerous group were middle-aged people - group 31-40 (31.9\%) and group 41-50 (29.8\%). The remaining age groups of respondents account for $12.1 \%$ respectively - group up to 30 years old, $9.3 \%$ - group $51-60$ years and $16.9 \%$ - age group over 60 years. Respondents answered questions related to:

- identification of cities in districts of the occurrence of perceived air pollution,

- causes of atmospheric air pollution in the city and health effects associated with polluted air,

- behavior of residents in the situation of the announced state of high air pollution,

- residents' expectations of the city government in improving air quality.

Survey questions were the nature of multiple-choice questions.

Identification of sources of air pollution according to the respondents' opinions In Zabrze, the main sources of air pollution are industrial plants, road transport and low emissions from home furnaces. In the city area there are two large heavy industry plants: a steel mill and a steel constructions plant. In the neighborhood of housing estates there is also a coking plant, which has a noticeable effect on the quality of air in the city. The problem of air pollution in this region is exacerbated by the fact that low emissions have increased mainly from home furnaces. In the survey, respondents indicated the most polluted districts of the Zabrze city. The analysis of the collected data shows that the most often indicated were the Biskupice district (234 responses), Konczyce (121 responses) and Centrum Południe (91 responses). Among the districts indicated by respondents, only the Biskupice district is located near a large heavy industry plant.

In the further part of the questionnaire, the respondents pointed to the sources of pollution, which they believe have the greatest impact on the deterioration of air quality in the city. The question suggested the following answers:

- car exhaust,

- burning of rubbish in furnaces by residents,

- burning fine coal or poor quality coal,

- pollution from industrial plants,

- inflow of pollution from the areas of neighboring cities,

- other factors.

Statistically, the answer was the most common: "the main source of air pollution in the city is the burning of rubbish by residents in domestic ovens" (502 responses). This means that as many as $86.6 \%$ of respondents indicated such a response. The burning of garbage in a prohibited way takes place in private homes, most often in the old generation furnaces of indigent people. The respondents decided that the combustion of fine coal or poor quality coal is an equally important source of air pollution. Such a response was indicated by 306 people from 580 respondents. Other indicated sources of pollution are in the order of: car exhaust, emissions from industrial plants, inflow of pollutants from another area.

The awareness that burning garbage in furnaces has a toxic effect on the environment is high among respondents of all age groups. For the three most frequently indicated 
responses, a bar chart of the absolute number of answers by age group was created. The response statistics are presented in Figure 1.

Factors affecting air pollution in the city according to respondents' opinions

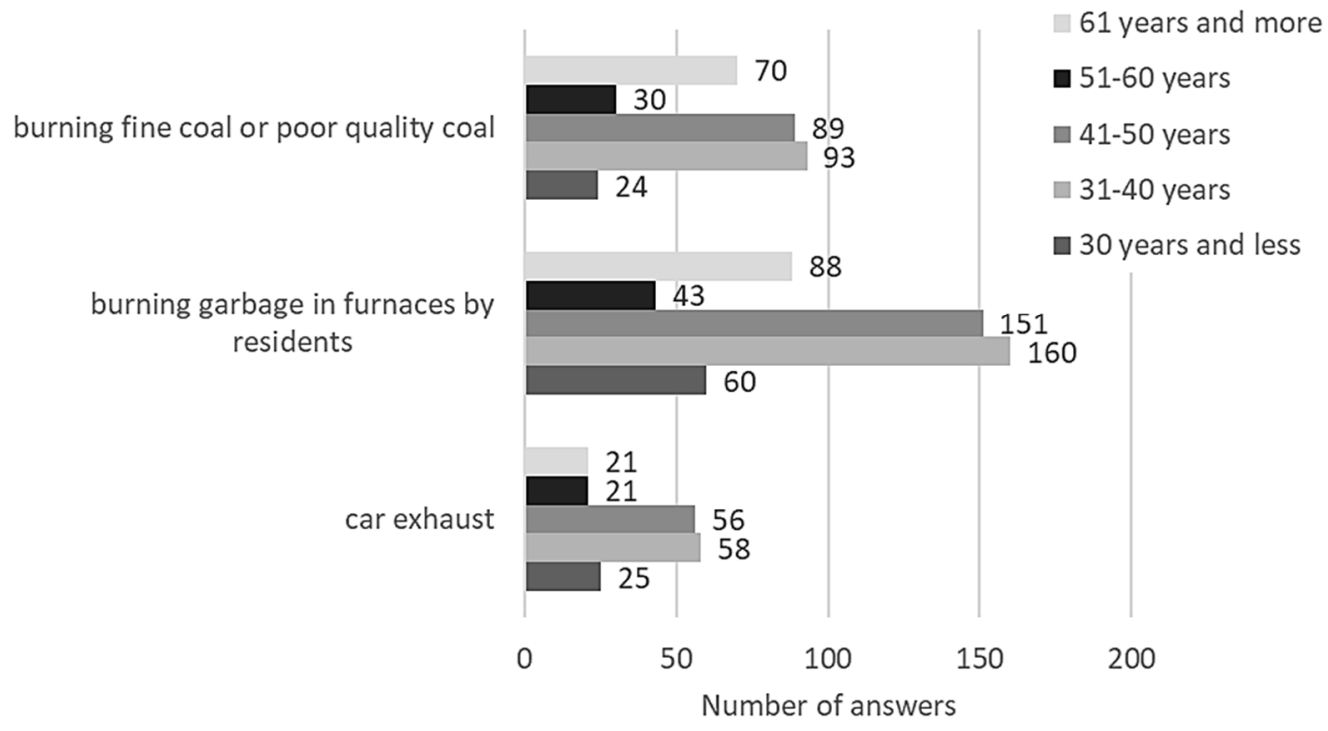

Fig. 1 Summary of the absolute number of respondents' answers to the question about factors affecting urban air pollution

Due to the fact that the group of examined middle-aged people (31-40 and 41-50 years) was the most numerous, the statistical results of the response per one respondent were also determined. In order to present a comparison of the number of answers provided in individual age groups, also the number of answers per one respondent in a given age group was calculated. This number was determined using the formula:

$$
W o=\frac{l o}{l g}
$$

where:

Wo - relative number of responses (per respondent),

10 - the number of answers in a given age group,

$\mathrm{lg}$ - the number of respondents in a given age group.

Figure 2 shows the relative number of responses to the question about the source of air pollution in the city of Zabrze. Answers: "factors affecting air pollution in the city are mainly the burning of garbage in domestic ovens" and "combustion of fine coal or poor quality of coal", which appear most often, are also the most frequently chosen responses in the group of seniors over 60 years. It follows that this group is aware of the environmental risks that incineration of rubbish or coal dust in furnaces. On the other hand, it is a group of indigent people, forced to save on the type of used fuel. However, in response: "factors affecting air pollution in the city are mainly car fumes", the age group 51-60 years gave statistically the most answers despite the fact that in Silesia for a long time indicates a low share of this type of source in air pollution. In addition, traffic in urban centers is limited in many cities. 


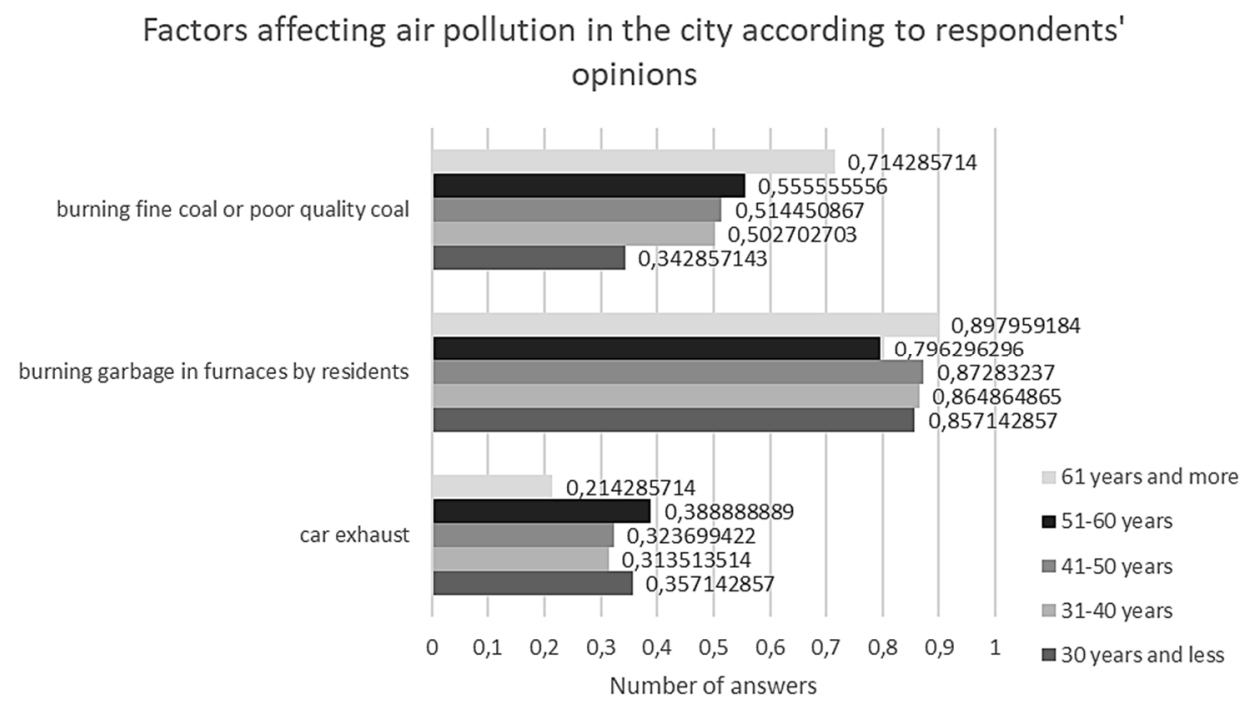

Fig. 2 Comparison of the relative number of answers (per respondent) to the question about factors affecting urban air pollution

\section{Health effects of air pollution in respondents' answers}

The survey also included issues related to knowledge and awareness of residents regarding the effects of air pollution on the human body. In the question about health effects that can be caused by air pollution, the following answers were suggested: "increased coughing", "breathing difficulties", "general malaise", "headaches", "discomfort associated with unpleasant odors" and other. Respondents could indicate several answers. Answer: "difficulty in breathing", the most frequent ones were 341 responses, i.e. $58.8 \%$ of all respondents (Figure 3 ).

Health effects caused by air pollution in the opinion of respondents

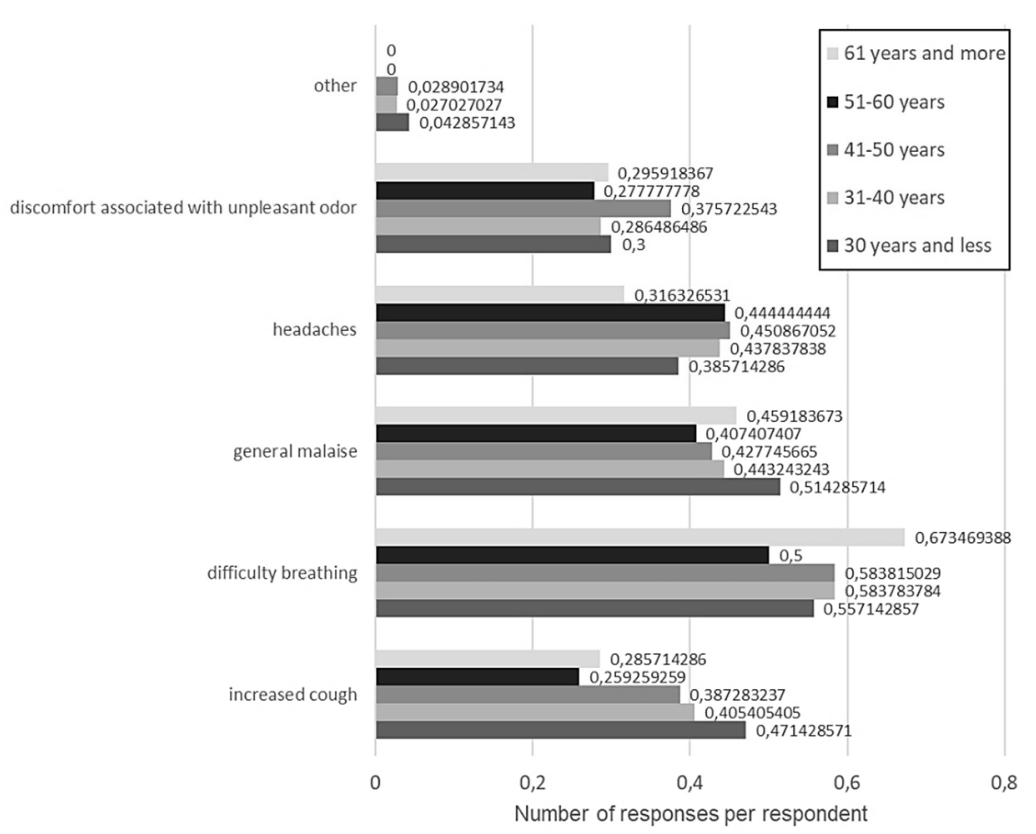

Fig. 3 Respondents' opinions on health effects caused by polluted air (statistics of relative values)

The answer "general discomfort" was indicated by 259 people, the answer: "headache" - 241 people, the answer: "increased cough" - 217 people and the 
answer: "discomfort associated with unpleasant smell" - 183 people. The presented graph in Figure 3 takes into account the age groups and the relative number of responses given. The influence of the age of the respondents on their opinion is visible. The relative number of responses was calculated from the dependence (1). Answer: "polluted air causes difficulties in breathing" and "general malaise", most often indicated respondents from the age group over 60 years. This group, due to advanced age, may be the most exposed to air pollution and feel the related problems. They form their opinion most probably on the basis of their everyday experiences. The questionnaire was also asked about the frequency of occurrence of breathing ailments in respondents and/or their relatives. Often and very often emerging difficulties in breathing were indicated by as many as 390 people, which is $67.2 \%$ of all respondents. 133 people, i.e. $23 \%$ of respondents, indicated rare occurrences of breathing. Persons who did not complain about breathing difficulties constituted only $3 \%$ of the respondents. Response statistics with regard to age groups are shown in Figure 4 (relative number of responses).

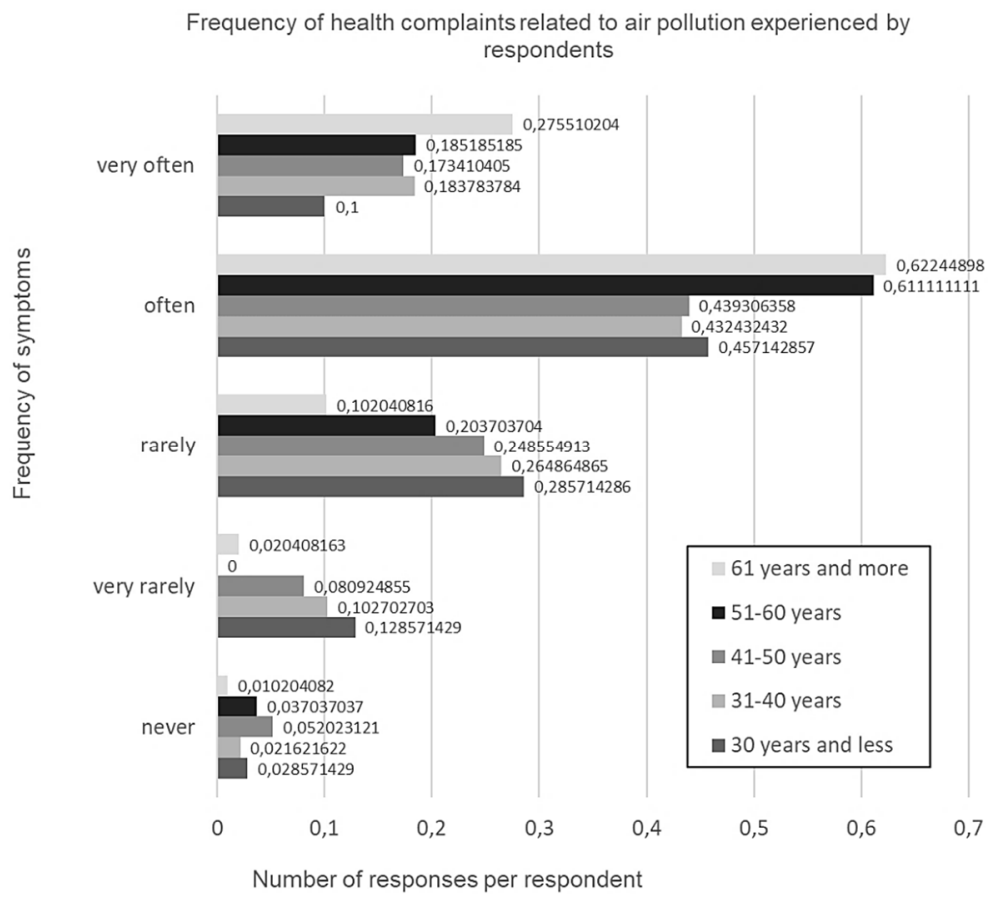

Fig. 4 Prevalence of complaints related to air pollution (statistics of relative values)

Answer: "respiratory complaints often appear", indicated the most people in the group of the oldest respondents (over 51 years). These two age groups, due to the generally more frequent age-related diseases, most often suffer from respiratory ailments. However, a surprisingly large age group (under 30 years) indicated frequent respiratory ailments. Almost every second (45 people out of 100) young man experiences respiratory ailments originating in polluted air. Also every other young person (under 30 ) indicated in the survey "general malaise" as a result of polluted air (Figure 3).

\section{Studying the behavior of residents in a situation of smog threat}

In this part of the survey, respondents (inhabitants of Zabrze) were asked about their actions when they learn about the poor quality of atmospheric air in a given region of 
their city. Respondents could indicate two answers. In general, the majority of respondents declare that they limit the time spent outside the building (411 responses). However, 149 people out of 580 respondents do not take any specific action. Only 32 people declared using smog masks. The statistics of these answers are presented in Figure 5 (data including age groups). In response, "other" respondents indicated different less popular answers such as: refraining from opening windows, leaving the city area, reporting the problem of municipal guards (mainly by elderly people), etc. Most people (mainly elderly people) limit the time spent in polluted air ( age group 51-60 and over 60 years), while passive behavior towards smog is declared primarily by young people - under 30 years of age.

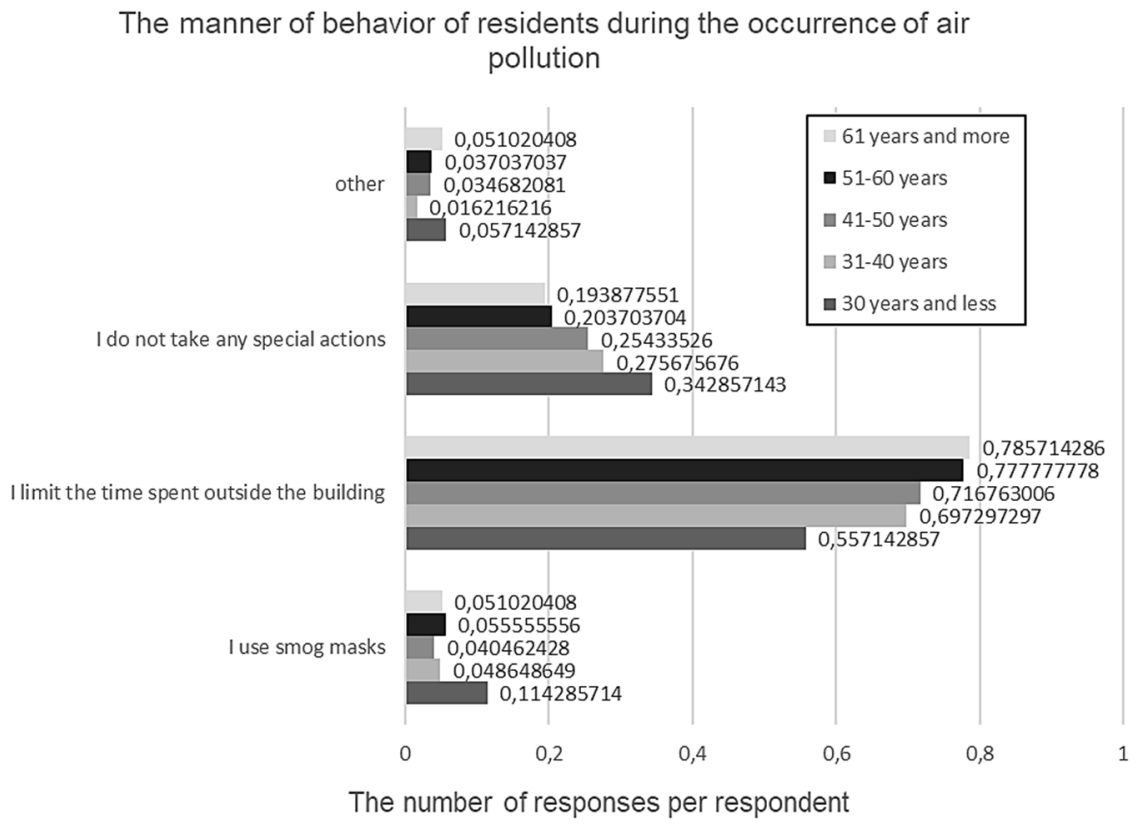

Fig. 5 Respondents' answers to the question about how to behave in conditions of polluted air (statistics of relative values)

\section{The effectiveness of preventive actions in the opinion of respondents}

In a situation of contaminated atmospheric air in the area of the city, and especially its densely populated areas (housing estates), it is necessary to take measures to improve air quality. The survey asked respondents what actions in their opinion may be most important to reduce air pollution in the city. The suggested answers include such activities as:

- residents using smog masks,

- reliable information on the current state of local air pollution,

- periodical (e.g. in the winter season) ban on entry of combustion vehicles to the city center,

- effective identification of impurities and penalties for people burning garbage in furnaces and outdoors,

- greater investments by municipal authorities in the modernization of furnaces for the least affluent residents.

The survey question was of multiple choice (Figure 6). The most responses were: "effective identification of pollutants and penalties for people burning garbage" (396 responses, or $68.3 \%$ of respondents) and "greater investments of the city in the 
modernization of home stoves" (363 responses). The activity consisting in reliable information on local air pollution was indicated by 195 respondents. Figure 6 presents the statistics of responses per respondent, including the division into age groups. As shown in the chart, mainly young people under 30 were in favor of introducing effective identification of air pollutants and penalties for burning rubbish. In this group, 3 people out of 4 respondents indicated such action as effective in combating air pollution in the city.

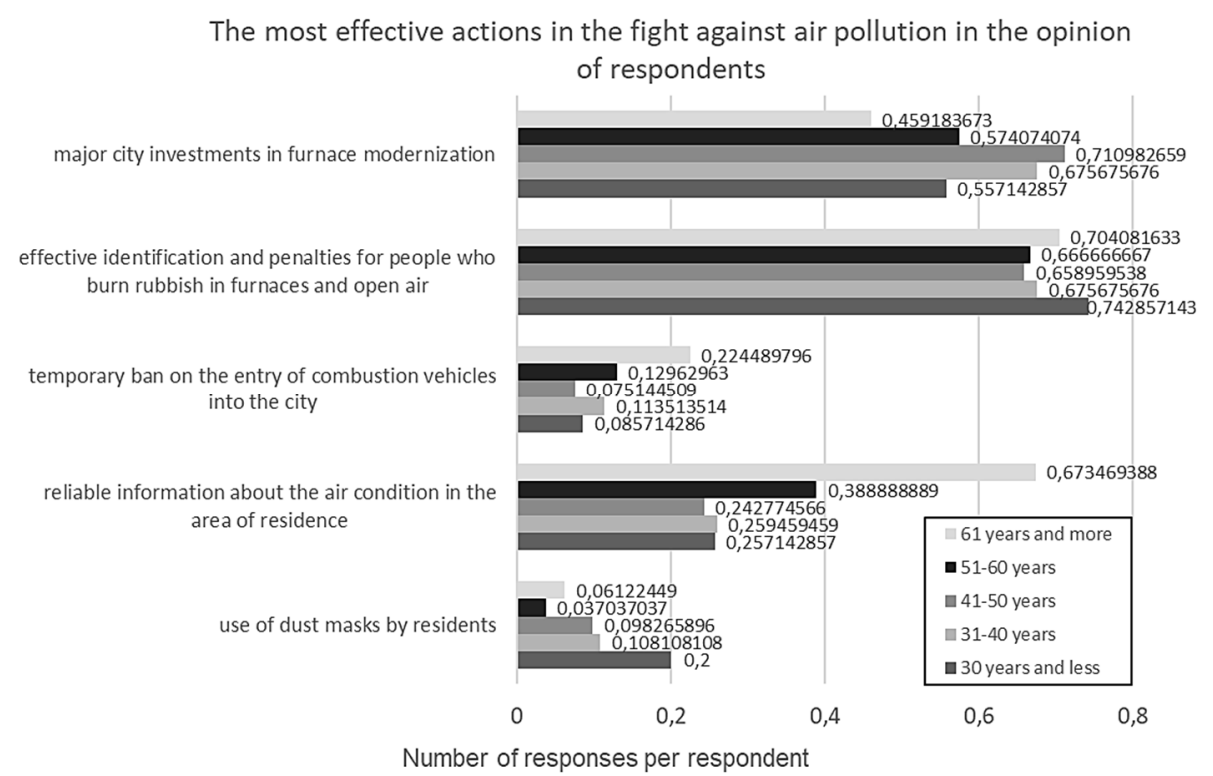

Fig. 6 Respondents' answers to the question about the most effective action in the fight against polluted air (statistics of relative values)

In turn, larger investments of the city in furnace modernization are the most frequently indicated response of middle-aged people - a group of people aged 31-40 and 4150. As shown in Figure 6, the answer: "reliable information about the local state of air quality", was chosen mainly by the oldest people (group of over 60 years).

\section{PREMISES FOR MANAGING THE URBAN ENVIRONMENT}

Environmental management in many Polish cities is based on activities included in the general development plans of the city, such as:

- reduction of low emissions by investments in replacement of heat sources in single-family houses,

- conducting detailed pollution monitoring in the city,

- co-financing the installation of solar collectors, photovoltaic installations and other renewable energy sources,

- co-financing of insulation of walls, replacement of windows for energy saving,

- thermomodernization of public utilities (reduction of energy consumption, thus reduction of pollutants emitted into the atmosphere),

- limiting road traffic in the area of city cents,

- development of electromobility,

- development of green areas and reclamation of degraded areas as a result of industrial activities and many more.

Such activities involve large investments, but they have a direct or indirect impact on 
the improvement of air quality in the city. On the other hand, they are insufficient and their positive effects are long-term. The expectations of the residents of the Zabrze, revealed in the research, are directed at more direct activities such as: reliable information on the local state of air quality, effective identification of air pollution and enforcement of penalties for incineration of rubbish, or greater investments of the city in the modernization of household furnaces.

Figure 7 presents a simplified algorithm of an exemplary data acquisition process for intelligent city management, the aim of which is to improve the lives of residents.

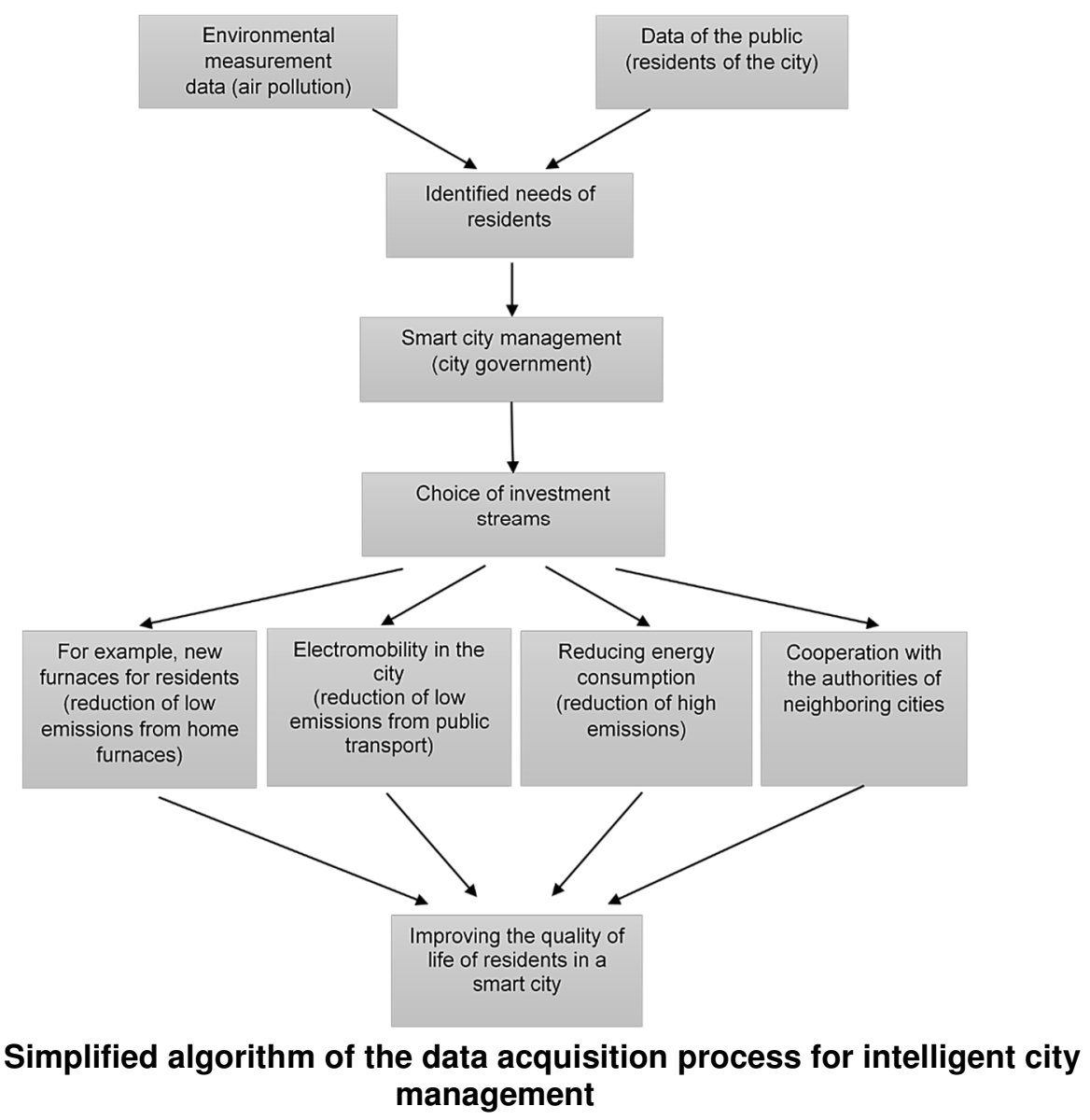

Modern cities are increasingly trying to take into account the opinion of residents in the city's development plans (Billert, 2012). There are examples of cities where the needs of residents become a priority for the city's managing authorities (Brzuśnian A., 2017, Copaja-Alegre \& Esponda-Alva, 2019, Jankowska, 2015). Participation of residents in city management is an element necessary for optimal satisfaction of their needs.

\section{CONCLUSIONS}

Surveys carried out among residents of the city struggling with polluted air have shown that the problem of smog is one of the most important elements affecting the life quality residents. The city management model should take into account the opinions of residents, encourage their expression and reliably take into account in financial policy by the city authorities.

The research carried out in the city of Zabrze allowed to identify priority actions for 
residents, such as:

- furnace replacement (investments),

- reliable air monitoring in the city,

- law enforcement among air polluters (waste incineration).

Actions to improve the quality of air, and thus the quality of life, can also be:

- raising awareness of the problem of air pollution (mainly due to the incineration of garbage, fine coal in furnaces that are not adapted to these purposes),

- construction of a warning system for smog threats to microregions (districts) of the city,

- increasing pro-ecological activity through the implementation of projects raising awareness of pro-ecological activities among adult residents, young people and children.

A systematic survey of public opinion in cities can be crucial in building a clean urban environment and improving the quality of life of its residents. Certainly, it will also allow for a more effective use of available financial resources to meet the real needs of city dwellers and including their co-management of urban space. The implementation of the idea of co-management of the city (use of human and social capital) can be differentiated by intelligent systems that collect and are able to process huge amounts of data (big data).

\section{REFEENCES}

Avveduto, A., Ferella, F., De Giovanni, M., Innocenzi, V., Pace, L. and Tripodi, P. (2017). L'Aquila Smart Clean Air City: The Italian Pilot Project for Healthy Urban Air. Environments, 4(4).

Bacco, M., Delmastro, F., Ferro, E. and Gotta, A. (2017). Environmental Monitoring for Smart Cities. IEEE Sensors Journal, 17(23), pp. 7767-7774.

Billert, A. (2012). Założenia, modele i planowanie polityki miast. Próba konfrontacji dwóch światów jednej Unii Europejskiej. In: K. Derejski, J. Kubera, S. Lisiecki, R. Macyra, ed. Deklinacja odnowy miast. Z dyskusji nad rewitalizacją w Polsce. Warszawa: Wyd. Naukowe Wydziału Nauk Społecznych.

Boryczka, E. (2016). Aktywność mieszkańców jako filar budowania społeczeństwa obywatelskiego. In: A. Nowakowska, Z. Przygrodzki, A. Rzeńcy, ed. EkoMiasto\#Społeczeństwo. Łódź: Wyd. Uniwersytetu Łódzkiego.

Brzuśnian, A. (2017). Wrocław jako przykład miasta inteligentnego. Prace Naukowe Uniwersytetu Naukowego we Wrocławiu, 470.

Cooper, C. D., Alley, F. C. (2011). Air pollution control: a design approach, Long Grove, Illinois: Waveland Press Inc.

Copaja-Alegre, M., Esponda-Alva, C., (2019). Technology and innovation towards the smart city. Advances, perspectives and challenges, Bitacora urbano territorial, 29(2), pp. 5970.

Dobrowolski, Z. (2005). Koncepcja społeczeństwa informacyjnego Daniela Bella. In: B. Sosińska, M. Przastek-Smokowa ed. Od informacji naukowej do technologii społeczeństwa wiedzy. Warszawa: Wyd. SBP.

Ignac-Nowicka, J. (2018b). Towards smart city: influence of air pollution on the local community of the Zabrze city in surveys and field research, in: MAPE 2018. XV International Conference Multidisciplinary Aspects of Production Engineering, 05-08 September 2018, Zawiercie, Poland. Conference proceedings, 1(1). [B.m.]: PANOVA, pp. 845-850.

Ignac-Nowicka, J.(2018a). Pilot research on air pollution in the Zabrze city for the idea of "smart city". In: 18th International Multidisciplinary Scientific GeoConference. SGEM 2018, 2 July - 8 July 2018, Albena, Bulgaria. Conference proceedings. Ecology, economics, education and legislation, 18(5.2), Ecology and environmental protection. Sofia: STEF92 Technology, pp. 699-706. 
Jankowska, M. (2015). Smart City jako Koncepcja Zrównoważonego Rozwoju Miasta przykład Wiednia. Studia i Prace Wydziału Nauk Ekonomicznych i Zarządzania Uniwersytetu Szczecińskiego, 42(2).

Kaczmarczyk, M., Pełka, G., Luboń, W., Będkowska, A., Piechowicz, Ł. and Ciapała, B. Niska emisja - od przyczyn występowania do sposobów eliminacji, Kraków: Wyd. Geosystem Burek, Kotyza s.c., pp. 144.

Korenik, A. (2019). Smart cities. Inteligentne miasta w Europie i Azji, Warszawa: Wyd. CeDeWu Sp. z o. o.

Kowalski, Ł. (2015). Inteligentne miasta - przegląd rozwiązań. In: M. Soja, A. Zborowski ed. Miasto w badaniach geografów, Kraków: Wyd. Uniwersytetu Jagiellońskiego.

Nam, T., Pardo, T. A. (2011). Conceptualizing Smart City with Dimensions of Technology. People and Institutions, Proceedings of the 12th Annual International Conference on Digital Government Research, 2011, College Park, USA, June 12-15.

Pikoń, K., Farooq Z.B. (2017). Solution for Gliwice smog problems, Gliwice: Wyd. Politechniki Śląskiej, Department of Technologies and Installations for Waste Management.

Rzeńca, A. (2016). Polityka Ekologiczna Miasta. In: A. Rzeńca, EkoMiasta\#Środowisko, Łódź: Wyd. Uniwersytetu Łódzkiego.

Stawasz, D., Sikora-Fernandez, D. (2016). Koncepcja smart city na tle procesów i uwarunkowań rozwoju współczesnych miast, Łódź: Wyd. Uniwersytetu Łódzkiego.

Szafraniec, M. (2017). Towards a „smart city” environmental management information system. In: 17th International Multidisciplinary Scientific GeoConference. SGEM 2017, 29 June - 5 July 2017, Albena, Bulgaria. Conference proceedings. Ecology, economics, education and legislation, 17(5.3), Environmental economics. Sofia: STEF92 Technology, 2017, pp. 997-1005.

Vallero, D. A. (2008). Fundamentals of air pollution, 4th ed., Amsterdam [etc.]: Elsevier: Academic Press.

Abstract. Managing the natural environment in the city is an important element of city management. Smart city authorities should take into account the opinion of residents about the comfort of living in the urban environment management strategy. A very important element of the natural environment in the city is air quality, which significantly affects the comfort of living in the city. The article presents surveys of opinions of the residents of a selected city in Silesia in Poland. The respondents' knowledge on the sources of air pollution in the city, the perceived health effects resulting from polluted atmospheric air and the expectations of residents towards the city authorities were examined using the anonymous questionnaire method. Residents' behavior in the situation of increased air pollution was also examined. On the basis of surveys, prophylactic pro-ecological activities were identified with the highest degree of acceptance of the local community as potential directions of urban environment management. The implementation of such activities, taking into account the opinions and preferences of the residents, is part of the co-management of the intelligent city.

Keywords: smart city, atmospheric air pollution, urban environment management, air quality monitoring 